\title{
Planning and Management of Digital Technologies in Municipal Education: A Case Study
}

\author{
Ada Augusta Celestino Bezerra ${ }^{1}$, Ronaldo Nunes Linhares ${ }^{1} \&$ Luciano Matos Nobre $^{1}$ \\ ${ }^{1}$ Tiradentes University of Sergipe, Sergipe, Brazil \\ Correspondence: Ada Augusta Celestino Bezerra, Postdoctoral Senior Education, Master and PhD in Education, \\ Professor of the Graduate Program in Education, Tiradentes University of Sergipe, Sergipe, Brazil.
}

Received: January 5, 2017

Accepted: February 9, 2017

Online Published: March 8, 2017

doi:10.20849/aes.v2i1.118

URL: https://doi.org/10.20849/aes.v2i1.118

\begin{abstract}
The article aims to analyze the limits and possibilities of the basic education management planning model, with a cut in the use of digital technologies in the public network. Its relevance is to demonstrate, through a case study, that the model implanted in a municipal education system as a response to the need for organic coexistence with digital technologies in education, needs to improve management practices and planning, re-discussion and re-elaboration. Legislation and experience help, but not always enough. He works concepts of Almeida (2009), Bezerra (2007), Bobbio (2000), Bordignon; Gracindo (2011), Frigotto (1995), Gramsci (1991), Luck (2011), Morin (2001) and Paro (2011). His final considerations contribute to the theoretical-practical discussions about the nature and extent of educational management in relation to Information and Communication Technologies (ICT), whose disruptive character lies in carrying the basic contradiction of facilitating and hindering the management of the school, in constant spiral of antithesis of oneself.
\end{abstract}

Keywords: democracy, education, management, planning, digital technologies

\section{Introduction}

In contemporary society there is a consensus in rejection of autocratic forms of government in all instances. In this perspective, the daily activities of the school institution, considering its social function and its role as exemplary in the practice of democratic exercise, it is expected the norteamento in collective action and cooperation between individuals. The road to democracy, as shown by Bobbio (2000), is to accept it as an apparatus of rules that define who makes the decisions and procedures.

We agree with the thesis Bobbio (2006), in that representative democracy is flanked or even replaced by a direct democracy, which was already stated by Rousseau (1712-1778), considered the father of modern democracy, which does not admitted the sovereignty represented. The States, historically and politically, have become larger, populous and complex; them no citizen is able to meet all others and dominate the entire legal apparatus that sustains them; customs also be complexificaram, with the multiplication of problems, new needs to be met, new rights to be created or updated and discussions; social inequalities have stoked progressively over the many historically constructed, crystallizing vices and perverse ethics that has crossed liberalism, neoliberalism and post-neoliberalism, as is the case of Brazil, where it grows the luxury, in the design of Rousseau, becomes corrupt while the rich and the poor: the first possession and the second with cupidity.

The different forms of management experienced in the various spheres of human life have been evaluated and end up causing the population to demand an extension of representative democracy or even the institution of direct democracy. It being understood by direct democracy literally the participation of all citizens in making / monitoring / evaluation of decisions (planning) relevant to them, may seem a foolish proposal maintain that everyone can decide on everything in complex societies, such as industrial something characterized nearly as possible.

From this perspective there is currently no representative state that the principle of representation only concentrate in parliament: the states that today characterize as representative they are because the principle of representation is extended to other sites, in which they take collective decisions (communes, provinces and in Italy, also the regions). Thus, not every representative state is a parliamentary state; Parliamentary State may not be a representative democracy. The existence of direct democracy in the proper sense of word, in which the 
individual participates in decisions concerning it implies that among individuals deliberative and decision concerning them there is no intermediary. This is the broad participation throughout the planning process.

The collegial administration has the school as a place essentially pedagogical significance in management, residing there the possibility of realization of essential public school function with the explanation of the following factors: an educational fact with participatory exercise democratic practice construction / socialization knowledge accumulated historically and decisions, as well as interaction of the school community and extraescolar in the educational project. Participation and democracy have meanings inseparable in building a modern collegial administration.

The globalization and the transformations that the technical-scientific development, especially those that information and communication technologies and undertake undertaken in society, established the Web as a space for building and nurturing relationships. Social networks established in cyberspace were consolidated as a public space that facilitates and universalized communication between people and data, with a participatory profile, interactive, hypermedia, collaborative and potentiating learning. ICT changed the agenda of communication and production, serving and consumption of knowledge. Common everyday to work and production relations, to new forms of political participation and collaboration, socio-cultural changes, until the spaces and forms of learning, ICT conformed the information to one of the most important elements of post-industrial society.

This study analyzes the educational management model implemented in the Municipal System of Aracaju Education, whose roots date back to the 1980s, from the hypothesis that a crossing models between concepts can / practices that already favor the participation to reach everyone in the democratic construction process, with the expansion of autonomy and participatory management, since mediated public policies, including integration of information and communication technologies, especially digital, the achievement of an inclusive school. It is the capital of the state of Sergipe, located in northeastern Brazil.

The objective is to analyze the limits and possibilities of the basic education management planning model, with a cut in the use of digital technologies in the public network. Its relevance is to demonstrate, through a case study, that the model implanted in a municipal education system as a response to the need for organic coexistence with digital technologies in education, needs to improve management practices and planning, re-discussion and re-elaboration.

\section{Conceptions of Management and ICT Policies in Education}

The educational management expression is the result of neoliberal discourse as an embedded concern in education from the contributions of scientific management in general. In recent years there has been an evolution towards the preservation of specificity of education, in the progressive perspective. Previous discussions focused on the administration as the object of opposing viewpoints: one that represented the adherence to the principles and procedures of capitalist management grounded in scientific management and the other denying the need for administration in the school context, as explained Paro (2010).

Today, the educational manager has to be requested in the institutional context, reflecting the expectation of dynamism and update that was needed to incorporate in educational institutions, without prejudice to their specific characteristics. Small is the probability of the state direct efforts for substantive democratization of knowledge without this being compelled by civil society. Sensitive changes are necessary in the context of Brazilian education for the country as a nation and people, can participate in the globalization of the economy and scientific-technical internationalization.

It was not only the educational sector who realized the need for change; in this regard the difficulties of survival in a new social and economic context forced the emergence of new ways in various areas of human coexistence in the direction of market regulation. In schools grows the realization of the explicit need of the community to participate effectively in the school management, with the vision to conquer and exercise their autonomy in relation to state interests.

The update of the potentials and overcoming the population share of obstacles in public school management represent social demands they face inside and outside the school, which does not correspond to the interests of ignoring or minimizing the conflicts that arise in social relations in progress and particularly at school. The proposition is to seek a democratization of school management, a necessary condition for the struggle of collective goals, aiming at a good quality education and the consolidation of a democratic society and educational values, which give rise to the broad participation of all citizens. 
In this perspective, Paro (1996) states need to be considered at the outset, the concept of administration or management that are taken as synonyms, leaving the management of design as the rational use of means for achieving an end. The adjectives of the administration or management as democracy is sustained in the vision of democracy, centered on the consensus of the majority of citizens and respect the rules established for the achievement of common goals.

The democratic process citizens believe in democracy, strengthening categories such as citizenship, diversity, antagonisms and conflicts (MORIN, 2001). Democracy presupposes the coexistence and the dialogic relationship between people who have a different way of thinking and goals. The key in this political factor is the existence of a new way to manage and administer, in which all the elements involved in building a participatory and social education, emphasizing the theoretical and practical category of citizenship, combined with the quality of basic education and teacher training.

By analyzing the educational management it is necessary to understand propositions that were built around the economics and the capital-labor contradiction assumed new specificities as the capital left for technological reconversion, business organization, combining the work forces and financial structures; companies abandoned the spaces in which the working class was more organized and historically been accumulating the conquest of rights, being located preferably in cities or areas where it was still incipient political organization of workers.

\subsection{The Issue of Management Participation}

In this context, the progressive political parties pointed to the theories of democratic participation of social subjects (collective) concrete, groups and social movements, without disregarding the role of fundamental social classes, to join forces with a view to positivity engendered by the crisis resulting from the collapse of the development model that served as a response to the Great Depression of the late 1920s: the Keynesian model, the state of social welfare or the welfare state, Fordism. The prospect that inspired the proposed transformation was still socialism whose historical form would be built by concrete men.

The new dilemmas posed particularly for education, considered the bourgeois project (with a partial view of analysis of reality) and the antagonistic interests of the workers (who see the school, institutions and social movements, hegemonic struggle spaces), had spawned a perplexity attitude in teachers, both in terms of an alternative project for society, including referring to relations of production, as a political-pedagogical proposal for public school and also to overcome the structural duality of the education system: education general versus vocational education, as Bezerra (2007) shows.

In statements Bordignon and Gracindo (2011), the analysis of the management of school education in the municipal school system, implies a reflection on the education policies since the management transforms educational goals and objectives, in actions aimed at political factor. "It must be beyond the current standards, commonly developed by bureaucratic organizations" (BORDIGNON; GRACINDO 2011, p.148).

Understand the management model developed in schools requires an analysis of programs and projects that are generated in the public educational policies, reviewing their proposals and strategies, creating new ways and paradigmatic vision that inspires them. Only then is it possible to identify and conduct a participatory way education enlarging the spaces and mechanisms of participation from the perspective of direct democracy, in which anyone give up their right to choose, opine and decide.

The need for reorientation in management models, from new economic agendas have in Information and Communication Technologies a double contribution. By acting in administrative and personnel dimensions, these technologies reinforce the propensity to organize and effectively regulate the bureaucratic demands of everyday school life. Software, notes systems and frequencies, electronic journals among others, meet the demand for organization, efficiency, effectiveness and control geared to produce results, as propensity of contemporary society for time work, the release of the physical effort that effect " positive "and facilitators in management.

\subsection{Current Demands of ICT for Education}

By acting on the pedagogical dimension the presence of ICT creates not much understood ramifications. These branches expose the limitations of a model of school and education, which has roots in curriculum design, training, learning and knowledge. ICT-mediated, the relationship between education and society; education and culture; education and power; education and knowledge they are reconfigured and can contribute, but also create conflicts within the classroom - in teaching and learning - the formation of oriented teachers to overcome the instrumentalist character, homogenised and disciplinarizante of teaching practice - and at school in management 
practices and planning focused on access, connection, technical contribution and organization of space / school time.

From the 1990s came together to school, almost simultaneously, a set of ICT integration policies and training managers who sought to meet the new socioeconomic requirements guided by the globalization of markets, different conceptions of work and modern communication settings, mediated by technology, which directly affect the educational ecosystem (Note 1).

With a delay of more than two decades, from proposing the art. 206 of the Federal Constitution of 1988 as one of the constitutional principles of public education, reaffirmed in the Law of Guidelines and Bases of National Education (Law No. 9394 \1996), establishing among its guidelines democratic management as a principle of national education, only in early twentieth century management has become a real concern of the Brazilian state. The need to build school management processes consistent with the proposal and the design of the social quality of education, the MEC in 2005 establishing the National Programme Managers School of Basic Education.

The first specialization course offered in this context, released that same year, had as a guiding principle, the fact that the democratic management of school units constitutes one of the dimensions that can contribute significantly to facilitate the right to education as a universal right. Among the objectives of this course are: i) contribute to the qualification of school manager from the perspective of democratic management and the realization of the right to basic education with social quality. ii) encourage managers to reflect on democratic management and develop management collegial practices in the school environment that promote civic education student; iii) To provide opportunities for managers to deal with technological tools that favor the collective work and the transparency of school management and iv) provide opportunities for managers to exercise innovative practices in planning and evaluation of school management.

Considering ICT as mediators of learning, several projects were implemented in the Brazilian school with analog technology since the early 1990s as the Video School (1987-1996) of the Bank of Brazil Foundation project developed in partnership with the Roberto Marinho Foundation and the State Education Departments, the Leap to the Future (1991) and TV school (1996), programs instituted by the federal government and still in action on TV school. With digital technology and the presence of computers in the Brazilian school space, Almeida (2009, p. 10) historically summarizes the project and experiences that defined the integration policies of these technologies into four phases:

First phase - [...] influenced by the disciples of Papert and Piaget called loguistas that from a Cartesian universe, too logical-mathematical, marked the time when the pre-PC computer, or PC with little memory and low processing power were used according to the logic of interaction with the machine from programming possibilities in the formal-logical universe of interaction between student / teacher, from the use of interfaces and commands LOGO4 language; • Second phase - [...] enters the picture skineriana design, which is based on machine vision transferring learn instructionist to the digital world and networking. This perspective has been strengthened from the government projects for the installation of computers in schools, implemented, for example, the widespread use of software for automation of offices and / or specific applications that turned the microcomputer in teaching machine, from a logic stimulus / response; • Third phase - [...] give rise to several projects in the logic of the so-called "educational portals" that seek to disseminate content and information with a view to centralized production and mass dissemination, according to methods already widely disseminated by media broadcasting standards. - Current phase - as a result of changing technologies and communication practices for the interactive patterns called web $2.0,[\ldots]$ new possibilities open up, however, must still be examined as potential because there are few educational initiatives such ownership resources with a view to harness its full potential $[\ldots]$.

In each phase was planned an effort to prepare teachers in this technology. Most of the time under the responsibility of states and municipalities; MEC directs these formations from the offer to the content and practices, a perspective that evolved from initial domain uses skills in a Salvationists vision of ICT for a proposed pedagogical reflection on its use at school. In addition to these examples of integration of ICT should also consider, both in management training, as the teachers an increasing influence on the domain and use classroom management software that include packages that allow: notes and frequencies, monitoring on- line of students, information for parents, digital diaries among others.

In the last twenty years, the school was invaded by a hand, an extramural sociocultural demand that has provided consistent changes in the way of learning of children and young people, on the other, is the scene of endogenous 
pressures, with ICT integration policies that require the school to at least "hang out" with these technologies. The manager is responsible to conduct this symphony, considering the different segments of the school community (parents, students, teachers, managers, technicians and support staff), looking through the democratic practice collaboration and participation.

\section{Management in Democratic Aracaju: A Model in Construction, with Advances and Kickers}

In Aracaju changing the traditional policy framework was outlined in 1985 with alliances between PMDB / PFL, supported by leftist parties like the PC do B and the Revolutionary Movement of 08 October (MR8) (Note 2). The administration of Aracaju Prefecture was taken over by the PMDB with Congressman José Carlos Mesquita Teixeira (fall of the Mayor Heraclitus Rolemberg) that in his short administration (1985) laid the foundations of democratic management.

According to Nobre (2014) the municipality of Aracaju, through the 1985 Magisterium of the Statute established by Mayor Jose Carlos Mesquita Teixeira, started to innovate with new ways of providing positions for the direction of public schools in Aracaju, where schools now have a new administrative organization. Aracaju, since then, gradually made some progress in the democratic management of the educational system, consolidating between 1989 and 1992. In relation to democratic educational administration, there has always been a union state demand in order to implement it, but state governments have opted for partial models of democratic school management through community committees and to tender what happened, but was suspended - for school director - always avoiding direct elections, including the governments of the workers' party.

The continuity of the democratic management process in the period (1989-1992) was surprising because it was contextualized in deep political, economic and financial crisis, which led to the emergence of seven strikes of teaching, besides the movement of technical and administrative staff, culminating in judicial lock the city's accounts in 1992. The administration of mayor Wellington Mota Passion (PSB), lived with impacts of the economic crisis in the country and presented from the beginning (1989) signals a deep internal political crisis. The systematization of the draft of the proposed curriculum developed with the municipal board of education is presented as wholesome contradiction in the dialectical movement of this reality. Also during this administration, some segments, including linked to the teachers' union of the municipal network as early as 1990 began to question the direct elections, which only strengthened the reaction of conservatives who were advancing in this direction in several parts of the country. This situation required firmness of purpose, especially in the Municipal Department of Education, in order to avoid setbacks in the democratic process (BEZERRA, 2007).

From the administration of former Mayor Jose Almeida Lima, from 1994 to 1996, direct elections in schools (Note3). In 1997, Law No. 2,491, of May 20, 1997, in João Augusto Gama management, created the Community Committees with the teaching units of Aracaju municipal network, to enable the Direct Money Federal Program for School. From 1997 to 2002, when it was suspended the election of directors, the established municipal government appointed people of their convenience for school leadership positions (BEZERRA and NOBRE, 2015).

Only in 2002 it set up a new management model of public school, with Law No. 3.075, of December 30, 2002 (Note 4), created by Mayor Marcelo Deda. Extinguished the function of the director, through the management to be exercised in each school by a Coordination Team: General coordinator, administrative coordinator and the educational coordinator. Depending on the school size (number of students), there is the possibility of having more of an administrative or teaching coordinator. According to Paro (2011) these elections for engineers in Aracaju education system have taken successively in 2003, 2005 and 2007, remaining to this day, which led to changes in the Career Plan of Aracaju Municipal Magisterium.

On the management experience of the municipality of Aracaju, surveyed some studies on this topic, we identified that focus around the democratic model installed on the premise that the democratic management is summarized in direct elections, as improved form since accompanied other mechanisms that constitute a collegial management. Bezerra (2007) portrays the Aracaju 1989-1992 experience. This author highlights advances of the municipal system of education with regard to teaching movement, as the contact with the community, with the exercise of democracy, developing progressive steps that constitute democratization, including towards the establishment and operation of School Boards and Elections direct to the direction of the network schools.

The theme is also attention in Noble studies (2014). In his Dissertation on the "school management model implemented in the municipal education Aracaju, 1993-2002" by updating the studies by the year 2002; Paro (2011) in his book "Critique of school structure," contributes to a discussion of the new coordination model, 
adopted by the City Hall of Aracaju. Other studies related to the period defined point to changes that design and management practice, they should not be necessarily as forward, as it goes on to talk in the election of a team of engineers, being visible fragmentation between the pedagogical and administrative in management of schools, as one can infer from reading Paro (2011). The escape of the word direction has implications for the practice of management, understood as a hegemonic direction component with its state and legal apparatus; however we need to consider the intellectual and moral direction north that is not reducible to Officer.

\section{Context of ICT Management in Aracaju}

Information and Communication Technologies (ICT) and in social processes have become part of the school environment, as noted earlier, both mandatory / endogenously, as exogenously by the students who, in possession of their mobile phones and devices bring cyberculture for school spaces. Communication achieves its objectives with information and different alternatives for the realization of a communicative practice.

The implementation of public policies does not happen a dialogic interaction between the planned and set up by states, municipalities, educational institutions, especially universities and the school itself. Programs and projects are designed and carried out as finished products for the entire school institutions, not observing the culture, context, space and place for its implementation and funding for their maintenance. School managements violate not always to this issue and its relevance as a social practice, as shown Coelho (2014).

According to Conceição and Silva (2012) the twenty-first century is a reflection on the practices developed in schools, enabling the maintenance of an education in line with society. In this new society of information and knowledge is essential to highlight the role / place of the teacher at a time when the quality of education has been linked, at least warned, as exclusively dependent on the school and the teacher.

In this society, they are developed all of human activity relationships, whether in the social, political, economic or educational. The technology enables a revolution in the learning process of human beings. Increasingly the intellectual market gains importance in the business world (p.88).

The school can not get off the evolution of the scientific process; You must walk encouraging instrumentation professionals, in everyday practice of teaching-learning process, directing education for this new century. It should be a space in which learning environments are created, facilitating students to experience and perform appropriate skills to their interests, considering the social requirements.

Since 1980 the Brazilian government has mobilized incentives for the implementation of Educational Informatics in Brazil with investments in policies of educational research sector. The National Programme for IT in Education - ProInfo, created by Ordinance no. 522 of 09 April 1997, the Ministry of Education is an example of this effort, whose purpose was to promote the educational use of technology in elementary and secondary public school system. In this sense,

ProInfo is considered a project with advanced form of organization. Your goals and guidelines were developed in extensive coordination and negotiation between the Secretariat of Distance Education (SEED / MEC), the National Council of State Secretaries of Education (CONSED) and computer state commissions in education, composed of representatives of the various municipalities of universities and the community in general. Among these representatives are educational planners, specialists in Educational Computing, teachers, parents and students (CONCEIÇÃO; SILVA, 2012, p.108).

\subsection{The Case of the Municipal Education System of Aracaju}

Sergipe both the state government and the municipality of Aracaju, through the Municipal Department of Education, have made the achievement of ProInfo, through the Department of Information Technology and Educational Technology Coordinator enabling computer labs teaching units 1 st to 5 th grade and 6th to 9th grade. 73 school units, from kindergarten to 9th grade as follows: 3 kindergartens, 25 schools from kindergarten, 24 schools from 1st to 5th year and 21 schools from 6th to 9th grade. Like the federal and state government, the government of the city of Aracaju has encouraged the integration of ICT policies within the school. Through Ordinance no. 522, April 9, 1997 the PROINFO, implanted computer labs in the network schools to maintain this program. In the municipal network, computer labs are present in 14 units of 1 to 5 and 20 schools from 6th to 9 th, presented in Table 1. 
Table 1. Basic education units with computer lab

\begin{tabular}{|c|c|c|c|c|}
\hline & SCHOOLS & $\begin{array}{l}1^{\circ} / 5^{\circ} \\
\mathrm{ANO}\end{array}$ & $6^{\circ} / 9^{\circ}$ ANO & PROJETO \\
\hline 01 & EMEF Alencar Cardoso & $\mathrm{X}$ & - & PROINFO \\
\hline 02 & EMEF José Carlos Teixeira & $\mathrm{X}$ & - & PROINFO \\
\hline 03 & EMEF Letícia Soares de Santana & $\mathrm{X}$ & - & PROINFO \\
\hline 04 & EMEF Mal Henrique Teixeira Lott & $\mathrm{X}$ & - & PROINFO \\
\hline 05 & EMEF Papa João Paulo II & $\mathrm{X}$ & - & PROINFO \\
\hline 06 & EMEF Maria da Glória Macedo & $\mathrm{X}$ & - & PROINFO \\
\hline 07 & EMEF Geraldo Barreto Sobral & $\mathrm{X}$ & - & PROJOVEM \\
\hline 08 & EMEF Oscar Nascimento & $\mathrm{X}$ & - & PROINFO \\
\hline 09 & EMEF Otília de Araújo Nascimento & $\mathrm{X}$ & - & PROINFO \\
\hline 10 & EMEF Prof. Diomedes Santos Silva & $\mathrm{X}$ & - & PROJOVEM \\
\hline 11 & EMEF Rachel Cortes Rollemberg & $\mathrm{X}$ & - & PROJOVEM \\
\hline 12 & EMEF Tenisson Ribeiro & $\mathrm{X}$ & - & PROINFO \\
\hline 13 & EMEF Olavo Bilac & $\mathrm{X}$ & - & PROJOVEM \\
\hline 14 & EMEF Dom Vicente Távora & $\mathrm{X}$ & - & PROJOVEM \\
\hline 15 & EMEF Presidente Vargas & - & $\mathrm{X}$ & PROINFO \\
\hline 16 & EMEF - Freitas Brandão & - & $\mathrm{X}$ & PROINFO \\
\hline 17 & EMEF - José Conrado de Araújo & - & $\mathrm{X}$ & PROINFO \\
\hline 18 & EMEF - Santa Rita de Cássia & - & $\mathrm{X}$ & PROINFO \\
\hline 19 & EMEF - Tancredo Neves & - & $\mathrm{X}$ & PROINFO \\
\hline 20 & EMEF - Laonte Gama & - & $\mathrm{X}$ & PROINFO \\
\hline 21 & EMEF - Florentino Menezes & - & $\mathrm{X}$ & PROINFO \\
\hline 22 & EMEF- Juscelino Kubitschek & - & $\mathrm{X}$ & PROINFO \\
\hline 23 & EMEF - Sérgio Francisco & - & $\mathrm{X}$ & PROINFO \\
\hline 24 & EMEF - Sabino Ribeiro & - & $\mathrm{X}$ & PROINFO \\
\hline 25 & EMEF - Manoel Bomfim & - & $\mathrm{X}$ & PROINFO \\
\hline 26 & EMEF - Carvalho Neto & - & $\mathrm{X}$ & PROINFO \\
\hline 27 & EMEF - Oviedo Teixeira & - & $\mathrm{X}$ & PROINFO \\
\hline 28 & EMEF - Thétis Nunes & & $\mathrm{X}$ & PROINFO \\
\hline 29 & EMEF - Jornalista Orlando Dantas & & $\mathrm{X}$ & PROINFO \\
\hline 30 & EMEF - Anísio Teixeira & & $\mathrm{X}$ & PROINFO \\
\hline & EMEF- José Antônio da C. Melo & & $\mathrm{X}$ & PROINFO \\
\hline 32 & EMEF - Jaime Araújo & & $\mathrm{X}$ & PROINFO \\
\hline 33 & EMEF - Olga Benário & & $\mathrm{X}$ & PROINFO \\
\hline 34 & EMEF - João Teles de Menezes & & $\mathrm{X}$ & PROINFO \\
\hline
\end{tabular}

Source: Secretaria Municipal de Educação de Aracaju/2015

In 2010, Law No. 12.249 of June 14, 2010, was implemented in public schools the A program Computer per Student (PROUCA), developed by the Presidency in association and coordination of the Ministry of Education, 
aimed at promoting educational and digital inclusion in the teaching-learning process, focusing on students and teachers of the Brazilian public schools with the use of laptops classified as educational laptops.

The PROUCA integrates plans, programs and educational projects, educational and digital inclusion technology, linking to the actions of the Education Development Plan - PDE and the National Educational Technology Program - ProInfo (Decree No. 6.300, of 12/12/2007). The program integrates more effectively to ProInfo, whose action training of education professionals to the educational use of technology in computer labs will be expanded and enriched with the use of portable equipment (CONCEIÇÃO; SILVA, 2012, P. 10)

The PROUCA - program a computer per student - the Aracaju municipality In 2012 made the delivery of 9,000 laptops in public schools in Aracaju. The PROUCA has a direct relationship with the PROINFO - National Educational Technology Program MEC, aimed at achievement of laptops in all schools Aracaju teaching the municipal to the enrichment proposition of the learning process of students and teachers, allowing access, mobility, interactivity, the digital world.

The dissemination of knowledge through this new tool available will contribute to the enhancement of the play in digital learning environments. The process of continuing education of teachers is developed under the guidance of UNDIME in partnership with ProInfo / MEC, through the NTE - Educational Technology Center - the Municipal Network Aracaju education, and coordination of the teaching staff of PROUCA-PMA- SE. The methodological theoretical axis of training prioritized the content of technological appropriation of PROUCA laptop and pedagogical activities of application possibilities developed with and for students contemplating the areas of knowledge of the school curriculum (CONCEIÇÃO; SILVA, 2012, p.10 / 11).

\subsection{Continuing Education as a Strategy for Organicity}

In Aracaju City Department of Education (Department of Information Technology and Educational Technology Coordinator) highlights schools that were awarded the UCA program.

Table 2. Units local, $6^{\circ}$ to $9^{\circ}$ year with UCA

\begin{tabular}{clc}
\hline & \multicolumn{1}{c}{ SCHOOLS } & LAP TOP - UCA \\
\hline 01 & EMEF Presidente Vargas & 106 \\
\hline 02 & EMEF - Freitas Brandão & 136 \\
\hline 03 & EMEF - José Conrado de Araújo & 49 \\
\hline 04 & EMEF - Laonte Gama & 700 \\
\hline 05 & EMEF- Juscelino Kubitschek & 109 \\
\hline
\end{tabular}

Source: Secretaria Municipal de Educação de Aracaju/2015

According to reports the Department of Information Technology and Educational Technology Coordinator, of the 21 schools that received the UCA Project, there is no detailed information on the amount of equipment in several units. The explanation is that in these schools the computers were delivered to the students, it is difficult to add up how many are still in use.

In addition to these projects, there are other technologies such as TV, DVD, acquired directly by schools through the school funding, which according to the City Department of Education, there is no control of the amount of these existing devices in schools and the detailed record in SEMED. Digital whiteboards by the central agency currently were also installed in twenty-two schools, whose managements are faced with operational problems in many of them as informed SEMED (2015): the audio does not work, broken VGA cables, trouble lamp and cable jack, jack cable cut, green image, then turns red and add the signal, USB cable problems, all cut cables, the board has been installed without the cables, the board was not installed ...

The Municipal Secretary of Education has installed integration schools and communications technology devices, through programs and projects funded by the MEC as PROUCA, PROINFO and LOUSA DIGITAL, among others, but it should be noted that, according to our observations these technologies, focus on digital whiteboards, need care since his installation as the maintenance so that they can be effectively used by teachers in schools, overcoming difficulties in their operation. 
The Office of Educational Technology - COTED of SEMED (2013 - 2014), has offered teacher training courses for the use of these new technologies to enter them in education (workshops; presencias courses and distance).

Table 3. Formations coted / semed

$2013-2014$

\begin{tabular}{lccc}
\hline \multirow{2}{*}{ WORKSHOPS } & \multicolumn{3}{c}{ NUMBER OF TRAINED TEACHERS } \\
\cline { 2 - 4 } & 2013 & 2014 & TOTAL \\
\hline Lousa & 115 & 87 & 202 \\
\hline Introdução a Educação Digital & 21 & - & 21 \\
\hline Elaboração de Projetos & 78 & - & 78 \\
\hline PPT (Slides) & - & 51 & 51 \\
\hline Áudio & - & 13 & 13 \\
\hline Blog & - & 14 & 14 \\
\hline & 214 & 175 & 389 \\
\hline
\end{tabular}

Source: SEMED (2015)

According to the data, between 2013 and 2014 there was a reduction in the number of enrolled in workshops and professional reduction courses of education. Whereas the computer labs were installed from 2005 and we do not have the training data from this period to 2013, for all training, before the creation of the Coordination of Educational Technologies - COTED (2013), it was under the responsibility of the State Department Education through the Education Technology Division - DITE, it is not possible to establish clearly how many teachers participated in training for use of ICT.

Among various technologies coming to school space enabling pedagogical mediation between school and school community, we note that since the inclusion of projects financed by the MEC as PROUCA, PROINFO and LOUSA DIGITAL or other institutions such as foundations like the Bank of Brazil and Roberto marine with Video School in the period (1987-1996), these technologies also come to schools by students in their everyday communication practices with mobile media, mainly mediated by digital technologies through social networks and their ramifications of communicative spaces because we are in a media society, living with technology.

All this set of innovations brings challenges and perplexities for school management. The use of these technologies at schools requires infrastructure as an important feature in the security with care, appropriate spaces influence the realization of these programs and projects; the absence of a technician to troubleshoot audio, no cables, lamps off the slates and others are frequent in various units.

Understanding the management model that has the democratic and technological requires an analysis of how policies driving and projects that are implemented as a single model, in which educational institutions try to adapt, regardless of your local / space inserted in the cultural process, which increases the responsibility without the proportional autonomy. The educational administration sets up so gradually as an arena of conflicts and pressures of antagonistic forces in everyday school life, as ratifies (LUCK, 2009).

Promote the culture of socialization is the purpose of school and management a means to achieve this end. When entering the school, directly or indirectly space, ICT, bring situations that require the manager a different look at the role of technology and its use, affecting the various dimensions of management such as the management of educational outcomes; democratic and participatory management, people management, educational management, administrative management, management of climate and school culture, management of daily school life.

SEMED / 2015 informs the creation of Educonexão (2013), in partnership with Net Company with a plan with cable TV and broadband internet in the computer labs and rooms management, to be implemented in various municipal schools. It also reports on digital whiteboards that came with the proposition to innovate and improve classrooms and at the same time, stimulate new pedagogical practices; in its initial period SEMED (2012) bought 60 digital whiteboards for their integration in schools.

In addition to these problems, it is necessary to understand the use of these technologies as a device that mediates the processes of learning and teaching, therefore, we must add the pedagogical dimension of 
management in relation to monitoring processes, training of professionals in continuous process and evaluation impact and results. The management of ICT at school requires, especially in the network which established a model of democratic management, a special look, a greater exercise of collaboration and participation of the school community in settings that affect all dimensions of management.

\section{Final Considerations}

We realize that democracy in its representative sense, must undergo a transformation process in the perspective of characteristics of a democracy characterized as direct. Direct democracy requires participation of all citizens in a new complex society that, before the industrialization process, try to create their own space of participation and direct decision, not abdicating their right in favor of representations, although not excluding construction a collective participation.

The organization has a collegiate manner in the public school your ideal space for realization of democratic practice with the participation of the school community as a collegiate management process. Liberal discourse brought concepts like education management expression that was replacing the use of term school administration. In current times we note the participation of educational managers in the construction of this new form of educational management.

The current configuration of the democratic management model of municipal public school system, with the coordination of positions, replacing the steering function, forgoing the Director of functions and Deputy Director that are common to most schools in the country and the world, besides representing a historical retrogression, is strengthening fragmentation preached by the scientific management (Taylorism and Fordism) and the neoliberalism (centralization, exclusion and control), at the expense of teaching autonomy, schools and the efficiency of ICT.

With the studies we observed that the Municipal Department of Education, has developed an effort to integrate schools and communication technologies, through programs and projects with own financing or MEC as PROUCA, PROINFO and others. The Office of Educational Technology has trained teachers, with the proposition of a democratic school, where public policies have implemented programs and projects with the viability of a democratic and technological school; but it is noticed that often there is no relationship with educational principles, not reaching its main goal, including the lack of maintenance so that its operation is achieved.

The prospect of a democratic management model that use technology in school requires the autonomy of the institution, with its demands and direction, including the creation of conditions of use in which highlights the planning process. The intentions of the central organ of the educational system should enable the demands of school units, providing them with the necessary infrastructure, not to enhance the disruptive nature of educational technologies. In this sense, it is very important to train managers and teachers, and creating, by managers, a collaborative space of knowledge production mediated by ICT.

The absence of political-pedagogical work of the school management before the implanted educational technology programs can cause this direction does not happen and technologies start to be laboratories or machines that take up spaces in schools, but lack the foundation of educational project. Not become effective social practices in school education space. In relation to ICT and the changes caused by them in society and culture, we can say that a collaborative management, not only effective in the legislation. The model implemented in Aracaju proves that, before the new, management and planning practices need to be renewed, rediscutias and reworked. Legislation and experience help, but are not always sufficient.

It is hoped that this article will contribute to the theoretical-practical discussions about the nature and extent of educational management in relation to Information and Communication Technologies (ICT), whose disruptive character lies in carrying the basic contradiction of facilitating and hindering school management, In a constant spiral of antithesis of oneself. Also the intention is to trigger new studies that deepen the theme.

\section{References}

Almeida, Doriedson Alves de. (2009). TIC e educação no Brasil: breve histórico e possibilidades atuais de apropriação Pró-Discente: Caderno de Prod. Acad.-Cient. Progr. Pós-Grad. Educação. Vitória 15(2), Ago./Dez..

Bezerra, Ada Augusta Celestino. (2007). Gestão democrática da construção de uma proposta curricular no ensino público: a experiência de Aracaju. Maceió: EDUFAL. 240 p. 
Bezerra, Ada Augusta Celestino. (2015, Org.). NOBRE, Luciano Matos. Gestão municipal: avanços e retrocessos. Fortaleza: Edições UFC.

Bobbio, Norberto. (2000). Estado, governo, sociedade: por uma teoria geral da política. Trad. Marco Aurélio Nogueira. Rio de Janeiro: Paz e Terra.

Bobbio, Norberto. (2006). O futuro da democracia. Trad. Marco Aurélio Nogueira. São Paulo: Paz e Terra.

Bordignon, Genuíno; GRACINDO, Regina Vinhaes. (2011). Gestão da Educação: o município e a escola. In: FERREIRA, Naura Syria Carapeto; AGUIAR, Márcia Angela da S. Gestão da educação: impasses, perspectivas e compromissos. 8.ed. São Paulo: Cortez.

Brasil. (1988). Constituição Federal. Brasília: Senado.

Brasil. (1996). MINISTÉRIO DA EDUCAÇÃO. Diretrizes e bases da educação nacional. Brasília: Editora do Brasil S/A.

Coelho, Lívia Andrade. (2014). Contextos de uma política pública: (des)caminhos dos governos para inserção de tecnologias digitais nas escolas públicas. Universidade Federal da Bahia. Faculdade de Educação. Pós-graduação em Educação, Salvador.

Conceição, Sheilla Silva da. (2012). Informática educacional na Rede Pública de Ensino Estadual: o PROINFO em Aracaju-SE. São Cristóvão: Editora UFS.

Conceição, Sheilla Silva da, \& SILVA, Roberto Carlos Delmas da. (2012). O programa um computador por aluno (PROUCA): conquistas e desafios na aprendizagem de alunos e professores da rede municipal de ensino de Aracaju-SE. VI Colóquio Internacional "Educação e Contemporaneidade". Universidade Federal de Sergipe, São Cristóvão-Se.

Frigotto, Gaudêncio. (1995). Educação e a crise do capitalismo real. São Paulo: Cortez.

Gramsci, Antônio. (1991). Concepção dialética da história. Trad. Carlos Nelson Coutinho. 9. ed. Rio de Janeiro, RJ: Civilização Brasileira.

Gramsci, Antônio (1991). Os intelectuais e a organização da cultura. Trad. Carlos Nelson Coutinho. 4. ed. Rio de Janeiro, RJ: Civilização Brasileira.

Luck, Heloisa. (2011). Gestão educacional: uma questão paradigmática. 8. Ed. Petrópolis, RJ: vozes. Série cadernos de gestão.

Morin, Edgar. (2001). Os sete saberes necessários à educação do futuro. Trad. Catarina Eleonora F. da Silva e Jeanne Sawaya. 4. ed. São Paulo: Cortez.

Nobre, Luciano Matos. (2014). Modelo de gestão escolar implementado na educação municipal de Aracaju, de 1993 a 2002. UNIT. (Dissertação de Mestrado em Educação)

Paro, Vitor Henrique. (2001). Gestão democrática da escola pública. 3. ed. São Paulo: Ática.

Paro, Vitor Henrique. (2010). Educação como exercício do poder: crítica ao senso comum em educação. 2. ed. São Paulo: Cortez.

Paro, Vitor Henrique. (1996). Eleição de diretores: a escola pública experimenta a democracia. Campinas: Papirus.

Paro, Vitor Henrique. (2001). Administração escolar: introdução crítica. 10. Ed. - São Paulo: Cortez.

Paro, Vitor Henrique. (2011). Crítica da estrutura da escola. São Paulo: Cortez.

Pereira, Max Augusto Franco. (2015). A lousa digital interativa como recurso para introdução da cultura de mídias digitais nas salas de aula da rede pública municipal de ensino de Aracaju. São Cristóvão, Se: UFS (Dissertação de Mestrado em Educação).

Semed/Pma. (1995). Lei $n^{\circ}$ 1.082/1985 de 24 de setembro de 1985. Aracaju.

Silva, Edilmara Vieria da Costa, DIAS, Rejane Isis Torres. (2013). Gestão democrática das escolas públicas no município de Aracaju: sob a ótica do período 1993-2002. UNIT. Aracaju.

\section{Notes}

Note 1. The ecosystem means that in a given environment, the geological bodies, geographical, physical, climatic (biotope) and the living beings of all species, unicellular bacteria, plants, animals (biocenosis), 
interretro-act with each other to generate and continually regenerate an organizing system or ecosystem produced by these same Inter-retro-actions. The interactions between living beings are not only of conflict, competition, competition, degradation and depredation, but also interdependencies, complementarities and solidarities. (...). Your process of self regulation integrates death in life, life in death. (Morin, Os problemas do fim de século). Lisboa, Editorial notícias, 1993 enxertos.

https://contadoresdestorias.wordpress.com/2007/06/04/o-pensamento-ecologizado-edgar-morin/. Capturado em $06 / 08 / 2015$.

Note 2. This is a political-ideological organization that rose up against the military dictatorship, whose proposal is socialist. Its name revenera memory "Che" Guevara in Bolivia captured on 08/10/1970.

Note 3. By Decree No. 169 of November 22, 1994, excluded the educational establishment secretary function of elections for filling of management positions in schools. On March 2, 1985 created the injunction against the City Council of Aracaju, based on the argument of unconstitutionality of Law No. 1,350 of January 20, 1988 which set elective criterion for providing the direction of the school system positions. This process generated Judgment No. 151 of March 19 de1997 it impossible from then carrying out the school direct elections in Aracaju.

Note 4. This document also repeals Law No. $2.491 / 1997$, extinguishing the Community Committees and expanding the School Councils already created since 1990 in order to assimilate the powers of the Community Committees.

\section{Copyrights}

Copyright for this article is retained by the author(s), with first publication rights granted to the journal.

This is an open-access article distributed under the terms and conditions of the Creative Commons Attribution license (http://creativecommons.org/licenses/by/4.0/). 